\title{
Review
}

\section{Starting to Shrink}

By John Eagles

Austin Macauley Publishers, 2017, £9.99 (pb), 338 pp.

ISBN: 9781786938541

John Eagles's first novel is a rollicking tale of a young psychiatrist in the early 1980s, on the threshold of his career.

Unfortunately, this promising career is nearly terminated as a consequence of various antics - alleged and otherwise - and the book culminates in a visit to the General Medical Council after the protagonist, Dr Douglas Barker, is accused of sexual misconduct with a patient.

This book was easy to read and something of a page-turner, but ultimately the characters were rather difficult to like. Douglas, who is clearly meant to be a nice chap, has a hint of arrogance that detracts from any potential sympathy for his plight. His approach to women centres on their appearance and he has no compunction in forming quick and easy relationships. There are allusions to his lost girlfriend, Spider, possibly in an attempt to account for his behaviour, but this is never really developed in a credible way. Most of the women in the book are minimally developed as characters, either presented as sexually attractive, needy, unpleasant or a combination of these. Pauline, a nurse who supports Douglas at his hearing, may be an exception. However, at the end of the book, Douglas rather disappointingly refers to her as sexy and it also becomes evident that she lied for him; suggesting that she may not be an exception after all.

Douglas's best friend, Chris, is another male psychiatric trainee from the west of Scotland, with a rather stereotypical accent and drinking habit. Both his educational supervisors are men and both of them are rather unlikely characters, particularly Dr Burlington, who speaks in a strange psychopathological manner, involving bizarre words that often start with consecutive letters of the alphabet. Dr Burlington is actually unbelievably nasty, but there is no hint as to why this is, which might have created some more tension. There are two female trainees in the story: Douglas has a fling with one before casting her off to Chris, the other achieves a liaison with the much older, married psychotherapy consultant. It would have been good to have incorporated an intriguing female character with a storyline beyond providing interest to the male characters of the book.

There is potential historical interest to current trainees, who may like to read about training practices and services nearly 40 years ago. Some things don't change and the patients' presentations and many treatments remain similar; but it is a very different job now.

However, my main difficulty with this book was the denouement (spoiler alert). Douglas was technically innocent because he had slept with the patient in question before she was a patient, and he had forgotten due to his previously unmentioned facial agnosia. But any opportunity for exploration of such an unusual ethical dilemma was then subsumed in a drunken train journey, in my view a great loss.

Dr Rebecca Lawrence (MPhil, MSc, MRCPsych) is a Consultant Psychiatrist at the Royal Edinburgh Hospital, Scotland; email: rebeccalawrence@nhs.net

doi:10.1192/bjb.2018.50

(c) The Authors 2018. This is an Open Access article, distributed under the terms of the Creative Commons Attribution-NonCommercial-ShareAlike licence (http://creativecommons.org/licenses/by-nc-sa/4.0/), which permits non-commercial re-use, distribution, and reproduction in any medium, provided the same Creative Commons licence is included and the original work is properly cited. The written permission of Cambridge University Press must be obtained for commercial re-use. 